\title{
Million Units
}

National Cancer Institute

\section{Source}

National Cancer Institute. Million Units. NCI Thesaurus. Code C67310.

A quantity equivalent to one million units (10E6 units). 